\title{
ALOKASI PENGELUARAN DAN KESEJAHTERAAN KELUARGA PADA KELUARGA NELAYAN BAGAN
}

\author{
Erni Widyaningsih $\left.{ }^{1 *}\right)$, Istiqlaliyah Muflikhati ${ }^{1}$ \\ ${ }^{1}$ Departemen IImu Keluarga dan Konsumen, Fakultas Ekologi Manusia, Institut Pertanian Bogor, \\ Bogor 16680, Indonesia \\ ${ }^{*}$ E-mail: erni.kk48@gmail.com
}

\begin{abstract}
Abstrak
Penelitian ini bertujuan untuk menganalisis alokasi pengeluaran dan kesejahteraan keluarga nelayan bagan. Penelitian dilakukan di Desa Sarang Tiung, Kecamatan Pulau Laut Utara, Kabupaten Kotabaru, Provinsi Kalimantan Selatan. Penelitian ini melibatkan 50 keluarga nelayan bagan yang dipilih secara acak sederhana. Data penelitian diperoleh melalui wawancara pada 50 orang suami dan 50 orang istri dengan menggunakan kuesioner. Variabel yang diukur meliputi karakteristik keluarga, alokasi pengeluaran, dan kesejahteraan keluarga. Data dianalisis dengan menggunakan uji deskriptif, uji korelasi, uji independent sample $t$-test, dan uji regresi linier berganda. Hasil penelitian menunjukkan proporsi pengeluaran pangan lebih besar $(61,06 \%)$ daripada pengeluaran nonpangan (38,94\%). Sebagian besar keluarga nelayan bagan termasuk dalam kategori keluarga tidak miskin berdasarkan indikator kesejahteraan objektif. Kesejahteraan subjektif suami lebih tinggi daripada kesejahteraan subjektif istri, terutama pada dimensi fisik-ekonomi. Terdapat perbedaan yang signifikan antara kesejahteraan subjektif suami dan kesejahteraan subjektif istri pada $p<0,001$. Kesejahteraan subjektif suami dipengaruhi oleh besar keluarga, pengeluaran kesehatan, dan pengeluaran komunikasi. Kesejahteraan subjektif istri dipengaruhi oleh jumlah bagan, pengeluaran komunikasi, dan pengeluaran kegiatan sosial.
\end{abstract}

Kata kunci: alokasi pengeluaran, kesejahteraan objektif, kesejahteraan subjektif suami, kesejahteraan subjektif istri, nelayan bagan

\section{Expenditure Allocation and Family Welfare of Bagan Fishermen Families}

\begin{abstract}
This research aimed to analyze family expenditure allocation and welfare of bagan fishermen. Research conducted in Sarang Tiung Village, Pulau Laut Utara Subdistrict, Kotabaru. This research involved 50 families who have a bagan consisting of 50 husbands and 50 wives selected by simple random sampling method. Data was collected by interview with wife and husband using questionnaire. Variables measured include of characteristics the family, expenditure allocation, and family welfare of bagan fishermen. Data was analyzed using descriptive, correlation test, independent sample t-test, and multiple linier regression test. The result showed a greater proportion of food expenditure $(61,06 \%)$ than nonfood expenditures $(38,94 \%)$. Most of bagan fisherman families are classified as nonpoor by objective welfare indicator. Husband well-being is higher than wife, especially in physical-economy dimension. There are significant difference between subjective well-being husband and wife with $p<0,001$. Subjective well-being the husband influenced by family size, health, and communication spending. Subjective well-being the wife influenced by amount of bagan, communication, and social activities spending.
\end{abstract}

Keywords: expenditure allocation, objective welfare, husband subjective well-being, wife subjective well-being, bagan fishermen

\section{PENDAHULUAN}

Indonesia merupakan negara maritim terbesar di dunia yang secara geografis memiliki lautan lebih luas daripada daratan dengan garis pantai $104.000,00 \mathrm{~km}^{2}$. Luas daratan Indonesia adalah 1.910.931,32 km dengan luas lautan sebesar $3.544 .743,9 \mathrm{~km}^{2}$ atau 64,97 persen dari total wilayah Indonesia (KKP, 2011). Besarnya potensi laut membuat
Indonesia memiliki berbagai sumber daya hayati, mineral, dan energi. Masyarakat yang tinggal di pesisir menggantungkan hidupnya dari sumber daya laut dengan mata pencaharian sebagai nelayan. Keluarga nelayan merupakan keluarga yang identik dengan kemiskinan. Selain itu, keluarga nelayan juga sering berfoya-foya ketika memperoleh pendapatan yang tinggi, nelayan juga menggunakan sebagian pendapatan untuk 
belanja keperluan dirinya sendiri, misalnya untuk mencari hiburan, minum-minuman, atau sekedar makan-makan di warung bersama teman-teman sesama nelayan, sehingga pendapatan yang dapat dibelanjakan untuk keperluan keluarga menjadi berkurang (Muflikhati et al., 2010).

Desa Sarang Tiung merupakan salah satu desa dengan mayoritas penduduk berprofesi sebagai nelayan bagan". Berbeda dengan nelayan pada umumnya, pada kondisi normal nelayan melaut empat sampai lima kali dalam seminggu dan nelayan hanya menunggu sampai bagan terisi oleh ikan kemudian nelayan dapat memanennya. Permasalahan yang sering dihadapi oleh nelayan Desa Sarang Tiung, Kecamatan Pulau Laut Utara adalah kerusakan yang terjadi pada bagan dan cuaca buruk yang tidak menentu. Hal ini membuat nelayan tidak dapat melaut karena dapat membahayakan jiwa. Kegiatan mencari ikan di laut akan menghadapi berbagai risiko yang dapat menghambat penghasilan keluarga nelayan. Risiko yang sering dialami oleh nelayan yaitu ketidakpastian produksi dan fluktuasi lingkungan untuk mengakses sumber daya ikan, risiko harga dari kondisi pasokan yang tidak stabil, dan risiko kerugian atas aset yang dimiliki bahkan mempertaruhkan nyawa dari kondisi laut (Crona et al., 2010).

Masyarakat yang tinggal di wilayah pesisir berjumlah 7,8 juta jiwa yang tersebar di 10.639 desa pesisir dan 2,2 juta jiwa diantaranya termasuk dalam kategori sangat miskin (KKP, 2011). Kecamatan Pulau Laut Utara merupakan kecamatan dengan kemiskinan tertinggi di Kabupaten Kotabaru dengan 1.744 rumah tangga miskin atau 8.730 jiwa yang berada di bawah garis kemiskinan (Iberahim, 2013). Pendapatan yang diperoleh nelayan sangat tergantung pada banyaknya hasil tangkapan yang berfluktuasi sesuai dengan musim (Muflikhati et al., 2010). Faktor-faktor yang berpengaruh terhadap pendapatan melaut adalah pendidikan, pengalaman melaut nelayan, dan daya mesin (Primyastanto et al., 2012). Pendapatan yang diperoleh akan dialokasikan untuk mencukupi kebutuhan primer maupun sekundernya baik konsumsi pangan maupun nonpangan (Rachman, Purwantini, \& Marisa, 2006). Berdasarkan teori Engel, semakin tinggi tingkat pendapatan maka persentase pengeluaran rumah tangga untuk konsumsi pangan akan mengalami penurunan. Mengacu pada teori tersebut maka keluarga dapat dikatakan sejahtera apabila persentase

\footnotetext{
${ }^{1}$ http://sarangtiung.desa.id/bagang-tancap/
}

pengeluaran untuk pangan semakin kecil dibandingkan dengan persentase pengeluaran nonpangan.

Salah satu indikator kesejahteraan keluarga adalah dengan mengukur besarnya pengeluaran keluarga. Pengeluaran keluarga dapat dibedakan menjadi dua, yaitu pengeluaran untuk kebutuhan pangan dan nonpangan. Pengeluaran pangan meliputi tindakan konsumsi terhadap bahan pangan kelompok padi-padian, ikan, daging, telur, sayuran, kacang-kacangan, minyak, lemak, dan buah-buahan. Sementara itu, pengeluaran nonpangan meliputi biaya untuk perumahan, bahan bakar, penerangan dan air, barang dan jasa, pakaian dan barang-barang tahan lama lainnya (BPS, 2008). Rata-rata pengeluaran keluarga, terutama pada keluarga miskin masih didominasi untuk pengeluaran pangan (Firdaus Apriliani, \& Wijaya, 2013; Girsang, 2012; Muflikhati, 2010; Rambe, Hartoyo, \& Karsin, 2008). Teori Engel menyatakan bahwa semakin tinggi tingkat pendapatan maka persentase pengeluaran rumah tangga untuk konsumsi pangan akan mengalami penurunan.

Kesejahteraan keluarga adalah keluarga yang dibentuk berdasarkan atas perkawinan yang sah, mampu memenuhi kebutuhan hidup spiritual dan materiil yang layak, bertaqwa kepada Tuhan Yang Maha Esa, memiliki hubungan yang serasi, selaras, dan seimbang antaranggota dan antara keluarga dengan masyarakat dan lingkungan (Sunarti, 2013). Kesejahteraan dapat diukur melalui kesejahteraan objektif dan kesejahteraan subjektif. Kesejahteraan objektif diukur dengan menggunakan empat belas indikator rumah tangga miskin penerima BLT dan garis kemiskinan Kabupaten Kotabaru. Kesejahteraan subjektif dapat diukur melalui tingkat kebahagiaan dan kepuasan yang dirasakan seseorang secara keseluruhan dalam hidupnya (Sunarti, 2006). Kelentingan keluarga berhubungan signifikan dengan kesejahteraan keluarga (Sunarti, Praptiwi, \& Muflikhati, 2011). Faktor-faktor yang memengaruhi kesejahteraan keluarga adalah besar keluarga, usia ayah, dan pendapatan keluarga (Elmanora, Muflikhati, \& Alfiasari, 2012). Hasil penelitian lain juga menemukan faktor-faktor yang memengaruhi kesejahteraan keluarga adalah pendidikan istri, kepemilikan aset, pendapatan, dan pekerjaan kepala keluarga (Iskandar, 2007). Keluarga sejahtera merupakan landasan awal terciptanya masyarakat yang harmoni. Dari keluarga sejahtera akan lahir sumber daya manusia yang berkualitas sehingga akan terwujud pula bangsa yang berkualitas. 
Berdasarkan pemaparan tersebut, penelitian ini bertujuan untuk menganalisis alokasi pengeluaran dan kesejahteraan keluarga nelayan bagan berdasarkan kesejahteraan objektif dan subjektif, serta menganalisis pengaruh karakteristik keluarga dan alokasi pengeluaran terhadap kesejahteraan subjektif keluarga.

\section{METODE}

Penelitian ini menggunakan desain cross sectional yang dilakukan di Desa Sarang Tiung, Kecamatan Pulau Laut Utara, Kabupaten Kotabaru, Provinsi Kalimantan Selatan. Pemilihan lokasi dilakukan secara purposive dengan pertimbangan keluarga nelayan di wilayah pesisir yang menggunakan bagan sebagai alat tangkap ikan. Waktu penelitian dilaksanakan pada bulan Februari sampai dengan bulan Maret tahun 2015. Populasi pada penelitian ini adalah keluarga nelayan bagan yang ada di Desa Sarang Tiung yang berjumlah 126 keluarga. Jumlah contoh dalam penelitian ini dipilih secara acak sederhana dengan jumlah contoh sebanyak 50 keluarga nelayan bagan, terdiri atas 50 orang suami dan 50 orang istri.

Jenis data yang digunakan pada penelitian ini adalah data primer yang meliputi karakteristik keluarga, alokasi pengeluaran, dan kesejahteraan keluarga nelayan bagan. Data primer diperoleh melalui wawancara dengan menggunakan alat bantu kuesioner sebagai panduan. Karakteristik keluarga terdiri atas usia, jenis kelamin, besar keluarga, lama pendidikan, pekerjaan, suku, lama menjadi nelayan, dan pendapatan keluarga per bulan.

Alokasi pengeluaran dalam penelitian ini dibagi menjadi pengeluaran pangan dan pengeluaran nonpangan. Pengeluaran pangan meliputi pengeluaran untuk pangan pokok, pangan hewani, sayur, buah, jajan, dan rokok, sedangkan pengeluaran nonpangan terdiri atas pengeluaran untuk kesehatan, bahan bakar memasak, transportasi, pendidikan, pakaian, bangunan, pajak, komunikasi, dan kegiatan sosial.

Kesejahteraan keluarga dibagi menjadi dua, yaitu kesejahteraan subjektif dan objektif. Kuesioner kesejahteraan subjektif menggunakan kuesioner yang dimodifikasi dari penelitian Sunarti (2001) dengan nilai Cronbach's alpha sebesar 0,905. Kesejahteraan subjektif diperoleh dengan menggunakan 20 pertanyaan yang terbagi ke dalam tiga dimensi yaitu dimensi fisik-ekonomi (8 pertanyaan), dimensi sosial (5 pertanyaan), dan dimensi psikologis (7 pertanyaan). Pertanyaan-pertanyaan tersebut diukur dengan menggunakan skala Likert dengan pilihan jawaban sangat tidak puas (skor 1), tidak puas (skor 2), puas (skor 3), dan sangat puas (skor 4). Selanjutnya skor yang diperoleh dari pertanyaan pada variabel kesejahteraan subjektif dikompositkan dengan mentransformasi nilai skor menjadi indeks dan dikategorikan menjadi tiga kategori, yaitu kesejahteraan subjektif rendah (indeks 0,050,0 ), sedang (indeks 51,0-75,0), dan tinggi (indeks 76,0-100,0).

Kesejahteraan objektif diukur dengan menggunakan 14 kriteria rumah tangga miskin penerima BLT dan berdasarkan indikator garis kemiskinan Kabupaten Kotabaru. Jika keluarga memenuhi satu kriteria maka mendapatkan skor 1, sebaliknya jika tidak memenuhi memperoleh skor 0 . Berdasarkan kriteria tersebut, keluarga dikelompokkan menjadi dua kategori, yaitu miskin jika (skor 6-14) dan tidak miskin (skor 6-14).

Analisis data yang digunakan pada penelitian ini adalah analisis deskriptif dan inferensial. Analisis deskriptif digunakan untuk menggambarkan karakteristik keluarga, alokasi pengeluaran, kesejahteraan objektif, dan kesejahteraan subjektif. Analisis inferensial yang digunakan meliputi uji korelasi, uji beda, dan uji regresi linier berganda. Analisis korelasi dilakukan untuk menganalisis hubungan antara karakteristik keluarga, alokasi pengeluaran, kesejahteraan objektif, dan kesejahteraan subjektif. Uji beda independent sample t-test digunakan untuk menganalisis perbedaan kesejahteraan subjektif suami dan istri. Uji regresi linier berganda dilakukan untuk menganalisis pengaruh karakteristik keluarga (usia suami/istri, lama pendidikan suami/istri, besar keluarga, jumlah bagan dan pendapatan keluarga), dan alokasi pengeluaran terhadap kesejahteraan subjektif keluarga. Model regresi yang digunakan sebagai berikut:

Model Regresi 1:

$Y_{1}=\alpha+\beta_{1} X_{1}+\beta_{2} X_{2}+\beta_{3} X_{3}+\beta_{4} X_{4}+\beta_{5} X_{5}+$ $\beta_{6} X_{6}+\beta_{7} X_{7}+\beta_{9} X_{9}+\beta_{10} X_{10}+\beta_{11} X_{11}+\beta_{12} X_{12}+\varepsilon$

Model Regresi 2:

$Y_{2}=\alpha+\beta_{1} X_{1}+\beta_{2} X_{2}+\beta_{3} X_{3}+\beta_{4} X_{4}+\beta_{5} X_{5}+$ $\beta_{6} X_{6}+\beta_{7} X_{7}+\beta_{8} X_{8}+\beta_{9} X_{9}+\beta_{10} X_{10}+\beta_{11} X_{11}+$ $\beta_{12} X_{12}+\varepsilon$

Keterangan:

$\mathrm{Y}_{1} \quad$ : Indeks Kesejahteraan subjektif istri

$\mathrm{Y}_{2} \quad$ : Indeks Kesejahteraan subjektif suami

$\alpha \quad$ : Konstanta regresi

$\beta_{1-13} \quad$ : koefisien regresi 



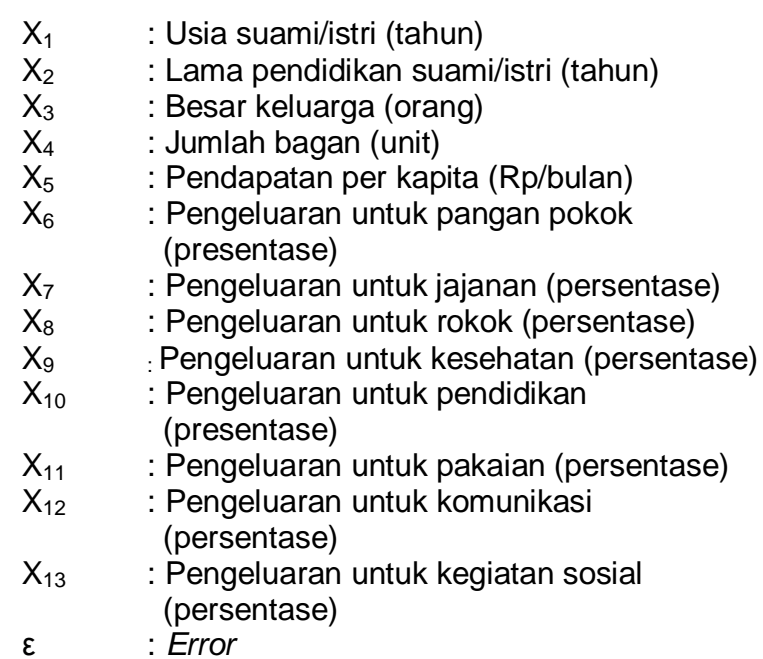

\section{HASIL}

\section{Karakteristik Keluarga}

Rata-rata usia suami lebih tinggi yaitu 44,22 tahun daripada rata-rata usia istri 38,76 tahun. Berbeda dengan usia, rata-rata lama pendidikan suami lebih rendah yaitu 5,56 tahun sedangkan rata-rata lama pendidikan istri 5,58 tahun. Jumlah anggota keluarga terdiri atas 2 sampai 10 orang dengan rata-rata berjumlah 4,84 orang. Jumlah bagan yang dimiliki oleh keluarga berkisar antara 1 sampai dengan 5 bagan dengan rata-rata berjumlah 1,7 bagan dengan rata-rata lama menjadi nelayan 15,26 tahun. Pendapatan keluarga adalah sejumlah uang yang diperoleh dari penjumlahan pendapatan seluruh anggota keluarga setiap bulannya. Pendapatan keluarga dalam penelitian ini merupakan gabungan jumlah uang yang diterima anggota keluarga dari bekerja di sektor perikanan dan nonperikanan. Sektor perikanan meliputi bagan, penggunaan alat tangkap lain, dan budidaya perikanan. Sektor nonperikanan terdiri atas pertanian, peternakan, serta usaha lain. Rata-rata pendapatan keluarga per bulan adalah sebesar Rp8.390.000,00. Adapun ratarata pendapatan per kapita keluarga sebesar Rp1.840.000,00.

\section{Alokasi Pengeluaran keluarga}

Rata-rata pengeluaran keluarga adalah sebesar Rp5.123.910,00 per bulan. Rata-rata pengeluaran yang dialokasikan untuk pangan per bulan adalah sebesar Rp3.228.500,00 per bulan atau sebesar 61,06 persen dari total pengeluaran keluarga. Sementara itu, alokasi pengeluaran untuk nonpangan keluarga adalah Rp1.895.410,00 per bulan yang mana lebih kecil dibandingkan dengan alokasi pengeluaran pangan.
Tabel 1 Alokasi pengeluaran keluarga dan pengeluaran per kapita

\begin{tabular}{|c|c|c|c|c|}
\hline \multirow{2}{*}{$\begin{array}{l}\text { Alokasi } \\
\text { Pengeluaran }\end{array}$} & \multicolumn{2}{|c|}{$\begin{array}{c}\text { Pengeluaran } \\
\text { keluarga }\end{array}$} & \multicolumn{2}{|c|}{$\begin{array}{c}\text { Pengeluaran per } \\
\text { kapita }\end{array}$} \\
\hline & $\begin{array}{l}\text { Rp000/ } \\
\text { bulan }\end{array}$ & $\%$ & $\begin{array}{l}\text { Rp000/ } \\
\text { bulan }\end{array}$ & $\%$ \\
\hline \multicolumn{5}{|l|}{ Pangan } \\
\hline Pangan pokok & 562,83 & 11,41 & 126,2 & 11,41 \\
\hline $\begin{array}{l}\text { Pangan } \\
\text { hewani }\end{array}$ & 350,02 & 6,47 & 78,76 & 6,47 \\
\hline Sayuran & 333,32 & 6,90 & 79,13 & 6,90 \\
\hline Buah & 78,98 & 1,45 & 18,70 & 1,45 \\
\hline Jajanan & 749,47 & 13,87 & 166,32 & 13,87 \\
\hline Rokok & 766,54 & 13,01 & 87,38 & 13,01 \\
\hline Lain-lain & 387,34 & 7,95 & 171,47 & 7,95 \\
\hline Subtotal & 3228,50 & 61,06 & 727,96 & 61,06 \\
\hline \multicolumn{5}{|l|}{ Nonpangan } \\
\hline Kesehatan & 227,00 & 4,86 & 49,66 & 4,86 \\
\hline $\begin{array}{l}\text { Bahan bakar } \\
\text { masak }\end{array}$ & 132,51 & 2,94 & 32,02 & 2,94 \\
\hline Transportasi & 181,83 & 3,79 & 39,83 & 3,79 \\
\hline Pendidikan & 523,60 & 10,20 & 104,69 & 10,20 \\
\hline Pakaian & 268,00 & 5,72 & 58,44 & 5,72 \\
\hline Perumahan & 45,66 & 1,14 & 11,70 & 1,14 \\
\hline Pajak & 24,23 & 0,52 & 5,42 & 0,52 \\
\hline Komunikasi & 233,10 & 4,46 & 49,31 & 4,46 \\
\hline $\begin{array}{l}\text { Kegiatan } \\
\text { sosial }\end{array}$ & 97,17 & 1,90 & 21,80 & 1,90 \\
\hline Lain-lain & 162,31 & 3,41 & 36,28 & 3,41 \\
\hline Subtotal & 1895,41 & 38,94 & 409,15 & 38,94 \\
\hline Total & 5123,91 & 100,0 & 1137,11 & 100,0 \\
\hline $\begin{array}{l}\text { Minimum- } \\
\text { Maksimum }\end{array}$ & \multicolumn{2}{|c|}{$\begin{array}{l}1875,66- \\
18470,10\end{array}$} & \multicolumn{2}{|c|}{$\begin{array}{l}387,53- \\
3694,95\end{array}$} \\
\hline $\begin{array}{l}\text { Rata-rata } \pm \\
\text { Standar } \\
\text { deviasi }\end{array}$ & \multicolumn{2}{|c|}{$\begin{array}{l}5123,91 \pm \\
2816,92\end{array}$} & \multicolumn{2}{|c|}{$\begin{array}{c}1137,11 \pm \\
6373,34\end{array}$} \\
\hline
\end{tabular}

Pengeluaran pangan pokok merupakan komponen pengeluaran pangan terbesar ketiga dalam pengeluaran. Pengeluaran untuk sayur dan pangan hewani tidak jauh berbeda, yaitu 6,90 persen untuk sayur dan 6,47 persen untuk pangan hewani. Proporsi pengeluaran pangan untuk buah memiliki persentase paling rendah karena keluarga jarang mengonsumsi buah. Proporsi terbesar pengeluaran pangan terdapat pada pengeluaran untuk jajanan yaitu 13,87 persen. Pengeluaran untuk rokok merupakan pengeluaran pangan terbesar kedua setelah jajanan. Dalam sehari, nelayan dapat menghabiskan satu sampai tiga bungkus rokok.

Rata-rata pengeluaran keluarga untuk kebutuhan nonpangan adalah Rp1.895.410,00 per bulan atau sebesar 38,94 persen dari total pengeluaran. Proporsi terbesar pengeluaran nonpangan terdapat pada pengeluaran untuk pendidikan, yaitu 10,20 persen. Pengeluaran terbesar kedua adalah pengeluaran yang dialokasikan untuk membeli pakaian. 

Pengeluaran untuk kesehatan merupakan pengeluaran terbesar ketiga setelah pengeluran pendidikan dan pakaian. Pengeluaran untuk kebutuhan komunikasi tidak jauh berbeda dengan pengeluaran untuk kesehatan. Keluarga dapat menghabiskan pulsa ratusan ribu hingga jutaan setiap bulannya. Pengeluaran untuk transportasi relatif kecil karena keluarga hanya menggunakan kendaraan untuk keperluan keluarga yang masih berada dalam satu desa yang sama. Mayoritas keluarga menggunakan minyak tanah dan kayu bakar untuk memasak sehingga pengeluaran untuk bahan bakar memasak menjadi relatif rendah.

Pengeluaran kegiatan sosial meliputi pengeluaran untuk peringatan Maulid Nabi, isra' Mi'raj, pernikahan, khitanan, macceretasi (pesta laut), ketika ada tetangga meninggal dunia, dan lain-lain. Saat kerabat atau tetangga sedang melaksanakan acara pernikahan atau khitanan biasanya keluarga menyumbang dalam bentuk uang dan sembako. Tradisi lainnya yang dilakukan masyarakat Desa Sarang Tiung adalah merayakan hari Maulid Nabi dan Isra' Mi'raj dengan membawa nasi bungkus. Masyarakat Desa Sarang Tiung juga memiliki acara adat yang rutin yang dilaksanakan setiap tahun, yaitu macceretasi atau pesta laut. Macceretasi dilaksanakan sebagai ungkapan rasa syukur nelayan atas hasil panen ikan satu musim yang lalu dan sebagai do'a agar pada musim selanjutnya hasil tangkapan lebih melimpah. Pada acara macceretasi ini setiap warga yang memiliki bagan wajib menyumbang, kecuali pemilik bagan sedang mengalami musibah. Sumbangan yang diberikan kepada tetangga yang meninggal dunia biasanya dalam bentuk uang, tetapi ada juga yang menyumbang dengan memberikan kain atau sarung.

Berdasarkan perbandingan antara pendapatan dan pengeluaran keluarga, pengeluaran keluarga seharusnya lebih sedikit daripada pendapatan yang diperoleh. Muflikhati (2010) menyebutkan terdapat tiga kondisi dalam pengelolaan keuangan keluarga, yaitu: 1) kondisi pada saat pengeluaran keluarga lebih rendah daripada pendapatan keluarga disebut dengan saldo surplus; 2) kondisi break even yaitu jika kondisi saldonya nol atau pengeluaran keluarga sama dengan pendapatannya; 3) jika pengeluaran keluarga lebih tinggi daripada pendapatan keluarga disebut dengan saldo defisit. Hasil penelitian ini menunjukkan bahwa pengeluaran keluarga nelayan bagan masih lebih besar daripada pendapatan. Hampir seperlima (16,0\%) keluarga dengan kondisi keuangan defisit.
Kondisi keuangan yang defisit membuat keluarga memerlukan dana tambahan seperti pinjaman, penjualan aset yang dimiliki, atau meminta bantuan dari pihak lain seperti saudara, tetangga, atau pemerintah.

\section{Kesejahteraan Objektif}

Kesejahteraan objektif diukur menggunakan 14 kriteria rumah tangga miskin. Sebaran keluarga berdasarkan kriteria tersebut disajikan pada Tabel 2.

Tabel 2 Sebaran keluarga (\%) berdasarkan kriteria rumah tangga miskin

\begin{tabular}{|c|c|c|c|}
\hline No & Kriteria & $\mathrm{Ya}$ & Tidak \\
\hline 1 & $\begin{array}{l}\text { Luas lantai bangunan tempat } \\
\text { tinggal }<8 \mathrm{~m}^{2} \text { per orang }\end{array}$ & 10,0 & 90,0 \\
\hline 2 & $\begin{array}{l}\text { Jenis lantai bangunan tempat } \\
\text { tinggal terbuat dari tanah/ } \\
\text { bambu/kayu murahan }\end{array}$ & 60,0 & 40,0 \\
\hline 3 & $\begin{array}{l}\text { Jenis dinding rumah terbuat dari } \\
\text { bambu/rumbia/kayu berkualitas } \\
\text { rendah/tembok tanpa diplester }\end{array}$ & 60,0 & 40,0 \\
\hline 4 & $\begin{array}{l}\text { Tidak memiliki fasilitas buang air } \\
\text { besar / bersama-sama dengan } \\
\text { rumah tangga lain }\end{array}$ & 60,0 & 40,0 \\
\hline 5 & $\begin{array}{l}\text { Sumber penerangan tidak } \\
\text { menggunakan listrik }\end{array}$ & 0,0 & 100,0 \\
\hline 6 & $\begin{array}{l}\text { Sumber air minum berasal dari } \\
\text { sumur/mata air tidak } \\
\text { terlindung/sungai/hujan }\end{array}$ & 4,0 & 96,0 \\
\hline 7 & $\begin{array}{l}\text { Bahan bakar untuk memasak } \\
\text { sehari-hari adalah kayu } \\
\text { bakar/arang/minyak tanah }\end{array}$ & 84,0 & 16,0 \\
\hline 8 & $\begin{array}{l}\text { Hanya mengkonsumsi susu/ } \\
\text { daging/ayam satu kali dalam } \\
\text { seminggu }\end{array}$ & 36,0 & 64,0 \\
\hline 9 & $\begin{array}{l}\text { Hanya membeli satu stel } \\
\text { pakaian baru dalam Setahun }\end{array}$ & 6,0 & 94,0 \\
\hline 10 & $\begin{array}{l}\text { Hanya sanggup makan se- } \\
\text { banyak satu/dua kali dalam } \\
\text { sehari }\end{array}$ & 6,0 & 94,0 \\
\hline 11 & $\begin{array}{l}\text { Tidak sanggup membayar biaya } \\
\text { pengobatan di puskesmas/ } \\
\text { poliklinik }\end{array}$ & 2,0 & 98,0 \\
\hline 12 & $\begin{array}{l}\text { Sumber penghasilan kepala } \\
\text { rumah tangga adalah petani } \\
\text { dengan luas } 0,5 \text { ha, buruh tani/ } \\
\text { nelayan, buruh bangunan, buruh } \\
\text { perkebunan/pekerjaan lain } \\
\text { dengan pendapatan } \\
<\text { Rp } 600.000 .00\end{array}$ & 0,0 & 100,0 \\
\hline 13 & $\begin{array}{l}\text { Pendidikan tertinggi kepala } \\
\text { rumah tangga tidak sekolah } \\
\text { /tidak tamat SD/tamat SD }\end{array}$ & 82,0 & 18,0 \\
\hline 14 & $\begin{array}{l}\text { Tidak memiliki tabungan/ barang } \\
\text { yang mudah dijual dengan nilai } \\
\text { minimal Rp500 } 000.00 \text { seperti; } \\
\text { sepeda motor, emas, ternak, } \\
\text { kapal motor, atau barang modal } \\
\text { lainnya }\end{array}$ & 0,0 & 100,0 \\
\hline
\end{tabular}



Hasil penelitian yang disajikan pada Tabel 2 menunjukkan bahwa masih terdapat satu dari sepuluh keluarga yang memiliki luas lantai $<8 \mathrm{~m}^{2}$. Lebih dari setengah keluarga memiliki lantai rumah yang terbuat dari kayu berkualitas rendah, sedangkan yang terbuat dari keramik hanya 16 persen, dan sisanya lantai terbuat dari kayu berkualitas baik. Kondisi serupa juga terjadi pada dinding tempat tinggal. Lebih dari setengah nelayan tidak memiliki jamban sendiri. Setengah dari nelayan melakukan aktivitas buang air besar di laut, satu dari sepuluh keluarga menggunakan fasilitas WC umum, dan hanya sepertiga dari nelayan yang memiliki WC pribadi. Aktivitas buang air besar di laut merupakan kebiasaan nelayan setempat sehingga bukan hal yang memalukan atau pun aneh saat mereka melakukan aktivitas buang air besar tidak pada tempatnya. Seluruh keluarga sudah menggunakan listrik sebagai sumber penerangan utama, meskipun masih ada keluarga nelayan yang menumpang aliran listrik dari tetangga. Hampir seluruh keluarga sudah menggunakan sumber air yang berasal dari sumber air terlindungi.

Sebagian besar keluarga (84,0\%) menggunakan bahan bakar minyak tanah dan kayu bakar. Kurang dari seperlima yang menggunakan gas sebagai bahan bakar memasak. Meskipun sudah memiliki dan menggunakan kompor gas, namun keluarga nelayan masih menggunakan minyak tanah dan kayu bakar dalam aktivitas memasak. Hal serupa juga terjadi pada keluarga di wilayah pesisir provinsi Jawa Barat. Hasil penelitian Muflikhati (2010) hanya kurang dari sepuluh persen yang menggunakan bahan bakar gas untuk memasak sehari-hari, pada umumnya keluarga yang memiliki kompor gas hanya menggunakannya sesekali sedangkan untuk memasak sehari-hari lebih suka menggunakan minyak tanah.

Hampir seluruh keluarga $(98,0 \%)$ mampu berobat ke puskesmas atau pun dokter saat anggota keluarga sedang sakit. Lebih dari seperempat nelayan hanya dapat mengonsumsi susu/daging/ayam seminggu sekali. Pada umumnya nelayan makan sehari tiga kali, bahkan lebih, dan hanya sedikit yang makan sehari dua kali, dengan alasan tidak terbiasa sarapan pagi. Pendidikan nelayan pada umumnya masih rendah. Hanya sedikit yang melewati jenjang sekolah dasar. Hal tersebut terjadi karena sejak kecil sudah ikut orang tuanya melaut dan karena keterbatasan ekonomi sehingga tidak dapat melanjutkan sekolah.
Sebaran keluarga berdasarkan kategori kesejahteraan keluarga menunjukkan sebanyak 24 persen keluarga termasuk dalam kategori miskin dan 76 persen tidak miskin berdasarkan 14 kriteria rumah tangga miskin penerima Bantuan Langsung Tunai (BLT) menurut Badan Pusat Statistik (BPS). Meskipun terdapat keluarga yang termasuk dalam kategori miskin, namun masyarakat Desa Sarang Tiung belum pernah mendapat bantuan untuk rumah tangga miskin dari pemerintah, termasuk BLT. Berdasarkan indikator garis kemiskinan yang ditetapkan oleh BPS Kabupaten Kotabaru, seratus persen keluarga termasuk dalam kategori tidak miskin. Garis kemiskinan BPS Kabupaten Kotabaru tahun 2013 adalah Rp294.832,00 per kapita per bulan.

\section{Kesejahteraan Subjektif}

Kesejahteraan subjektif yang diteliti adalah keadaan yang dirasakan oleh keluarga yang meliputi tiga dimensi, yaitu dimensi fisikekonomi, sosial, dan psikologis. Kesejahteraan keluarga secara fisik-ekonomi terdiri atas keadaan makanan, pakaian, tempat tinggal, kesehatan, pendidikan, pendapatan, aset, dan tabungan. Secara sosial terdiri atas partisipasi dalam masyarakat, hubungan antar anggota keluarga, tetangga, keluarga besar, dan kepuasan terhadap bantuan yang telah diberikan kepada orang lain. Secara psikologis terdiri atas rasa aman terhadap gangguan kejahatan, keadaan mental dan spiritual keluarga, serta pelaksanaan fungsi dan peran sebagai suami dan istri.

Tabel 3 menyajikan kepuasan keluarga berdasarkan dimensi fisik-ekonomi, sosial, dan psikologis. Pada tabel tersebut dapat dilihat bahwa dari tiga dimensi kesejahteraan subjektif, dimensi fisik-ekonomi merupakan dimensi yang memiliki rata-rata paling rendah daripada dimensi sosial dan dimensi psikologis baik suami maupun istri. Sebanyak 70,0 persen istri merasa kesejahteraan fisik-ekonominya masih rendah, serta tidak terdapat istri yang kesejahteraan fisik-ekonominya termasuk ke dalam kategori tinggi. Nilai minimum yang diperoleh istri adalah 25,0 dan nilai maksimumnya adalah 66,67.

Penyebab kesejahteraan subjektif istri dalam kategori rendah adalah banyak istri yang kurang puas dengan makanan, pakaian, kondisi rumah, kemampuan dalam membiayai kesehatan, pendidikan anak, pendapatan, aset, dan tabungan. Berbeda dengan istri, sebanyak 66,6 persen suami merasa kesejahteraan dimensi fisik-ekonomi berada dalam kategori 

sedang, satu dari 5 keluarga merasa kepuasannya tinggi, dan sisanya $(10,0 \%)$ termasuk dalam kategori rendah. Nilai minimum yang diperoleh suami adalah 33,3 dan nilai maksimumnya adalah 100,0.

Hampir seluruh istri merasa kesejahteraan subjektif pada dimensi sosial dan psikologis termasuk dalam kategori sedang. Hampir setengah suami $(48,0 \%)$ merasa kesejahteraan subjektif pada dimensi sosial termasuk dalam kategori tinggi dan tiga dari sepuluh suami merasa kesejahteraan subjektif pada dimensi psikologis termasuk dalam kategori tinggi. Hasil analisis uji beda menggunakan uji t menunjukkan kesejahteraan subjektif istri dan suami berbeda signifikan $(\alpha<0,001)$. Rata-rata kesejahteraan subjektif istri apabila dilihat dari masing-masing dimensi memiliki nilai rata-rata lebih rendah daripada nilai rata-rata suami.

Tabel 3 Sebaran, nilai minimum, nilai maksimum, nilai rata-rata, standar deviasi, dan koefisien uji beda untuk kesejahteraan subjektif keluarga

\begin{tabular}{|c|c|c|c|c|}
\hline \multirow{2}{*}{$\begin{array}{l}\text { Kesejahteraan } \\
\text { Subjektif }\end{array}$} & \multicolumn{2}{|c|}{ Istri } & \multicolumn{2}{|c|}{ Suami } \\
\hline & $\mathrm{n}$ & $\%$ & $\mathrm{n}$ & $\%$ \\
\hline \multicolumn{5}{|c|}{ Dimensi fisik-ekonomi } \\
\hline Rendah $(0,0-50,0)$ & 35 & 70,0 & 5 & 10,0 \\
\hline $\begin{array}{l}\text { Sedang }(51,0- \\
75,0)\end{array}$ & 15 & 30,0 & 33 & 66,0 \\
\hline $\begin{array}{l}\text { Tinggi }(76,0- \\
100,0)\end{array}$ & 0 & 0,0 & 12 & 24,0 \\
\hline Total & 50 & 100,0 & 50 & 100,0 \\
\hline $\begin{array}{l}\text { Minimum- } \\
\text { Maksimum }\end{array}$ & \multicolumn{2}{|c|}{$25,00-66,67$} & \multicolumn{2}{|c|}{$33,30-100,00$} \\
\hline $\begin{array}{l}\text { Rata-rata } \pm \text { Standar } \\
\text { Deviasi }\end{array}$ & \multicolumn{2}{|c|}{$45,41 \pm 12,63$} & \multicolumn{2}{|c|}{$69,54 \pm 16,20$} \\
\hline \multicolumn{5}{|l|}{ Dimensi sosial } \\
\hline Rendah $(0,0-50,0)$ & 0 & 0,0 & 0 & 0,0 \\
\hline $\begin{array}{l}\text { Sedang }(51,0- \\
75,0)\end{array}$ & 48 & 96,0 & 26 & 52,0 \\
\hline $\begin{array}{l}\text { Tinggi }(76,0- \\
100,0)\end{array}$ & 2 & 4,0 & 24 & 48,0 \\
\hline Total & 50 & 100,0 & 50 & 100,0 \\
\hline $\begin{array}{l}\text { Minimum- } \\
\text { Maksimum }\end{array}$ & \multicolumn{2}{|c|}{$60,00-100,00$} & \multicolumn{2}{|c|}{$53,33-100,00$} \\
\hline $\begin{array}{l}\text { Rata-rata } \pm \\
\text { Standar Deviasi }\end{array}$ & \multicolumn{2}{|c|}{$68,13 \pm 6,49$} & \multicolumn{2}{|c|}{$80,94 \pm 13,93$} \\
\hline \multicolumn{5}{|l|}{ Dimensi psikologis } \\
\hline Rendah $(0,0-50,0)$ & 2 & 4,0 & 0 & 0,0 \\
\hline $\begin{array}{l}\text { Sedang }(51,0- \\
75,0)\end{array}$ & 47 & 94 & 33 & 66,0 \\
\hline $\begin{array}{l}\text { Tinggi }(76,0- \\
100,0)\end{array}$ & 1 & 2,0 & 17 & 34,0 \\
\hline Total & 50 & 100,0 & 50 & 100,0 \\
\hline $\begin{array}{l}\text { Minimum- } \\
\text { Maksimum }\end{array}$ & \multicolumn{2}{|c|}{$47,62-76,19$} & \multicolumn{2}{|c|}{$52,38-90,48$} \\
\hline $\begin{array}{l}\text { Rata-rata } \pm S t a n d a r \\
\text { Deviasi }\end{array}$ & \multicolumn{2}{|c|}{$61,71 \pm 5,08$} & \multicolumn{2}{|c|}{$70,38 \pm 9,77$} \\
\hline$p$-value & \multicolumn{4}{|c|}{$0,000^{* *}$} \\
\hline
\end{tabular}

\section{Pengaruh Karakteristik Keluarga dan Alokasi Pengeluaran terhadap Kesejahtera- an Subjektif Keluarga}

Variabel yang dimasukkan dalam model yang memengaruhi kesejahteraan subjektif istri adalah karakteristik keluarga yang terdiri atas usia istri, lama pendidikan istri, besar keluarga, jumlah bagan, pendapatan per kapita, dan alokasi pengeluaran yang meliputi pengeluaran pangan pokok, jajanan, kesehatan, pendidikan, pakaian, komunikasi, dan kegiatan sosial. Koefesien regresi pengaruh karakteristik keluarga dan alokasi pengeluaran terhadap kesejahteraan subjektif keluarga (kesejahteraan subjektif istri dan kesejahteraan subjektif suami) disajikan pada Tabel 4.

Model regresi untuk kesejahteraan subjektif istri memiliki nilai adjusted $R$ square sebesar 0,148 . Hasil analisis menunjukkan bahwa jumlah bagan $(\beta=2,112 ; \quad p<0,1)$, pengeluaran untuk komunikasi $(\beta=0,874$; $p<0,05)$, dan pengeluaran untuk kegiatan sosial $(\beta=1,705 ; p<0,1)$ berpengaruh signifikan positif terhadap kesejahteraan subjektif istri. Jumlah bagan berpengaruh positif berarti bahwa setiap kenaikan 1 satuan jumlah bagan yang dimiliki oleh keluarga akan menaikkan kesejahteraan subjektif istri sebesar 2,112 satuan. Pengeluaran komunikasi berpengaruh positif menunjukkan bahwa setiap kenaikan 1 persen pengeluaran komunikasi akan menaikkan kesejahteraan subjektif istri sebesar 0,874 satuan. Selanjutnya, pengaruh positif dari pengeluaran untuk kegiatan sosial dapat diartikan dengan setiap kenaikan 1 persen pengeluaran kegiatan sosial akan menaikkan kesejahteraan subjektif istri 1,705 satuan.

Model regresi kesejahteraan subjektif suami memiliki nilai adjusted $R$ square sebesar 0,190 . Hasil analisis menunjukkan bahwa besar keluarga $(\beta=-1,994 ; p<0,1)$ dan pengeluaran untuk kesehatan $(\beta=-1,669 ; \quad p<0,1)$ berpengaruh signifikan negatif terhadap kesejahteraan subjektif suami. Hal ini berarti setiap kenaikan 1 satuan besar keluarga akan menurunkan kesejahteraan subjektif suami sebesar 1,994 satuan dan setiap kenaikan 1 persen pengeluaran untuk kesehatan akan menurunkan kesejahteraan subjektif suami sebesar 1,669 satuan. Selain itu, pengeluaran untuk komunikasi $\quad(\beta=1,520 ; \quad p<0,05)$ berpengaruh positif signifikan terhadap kesejahteraan subjektif suami. Hasil ini mengindikasikan bahwa setiap kenaikan 1 persen pengeluaran komunikasi akan menaikkan kesejahteraan subjektif suami sebesar 1,520 satuan. 

Tabel 4 Koefesien regresi pengaruh karakteristik keluarga dan alokasi pengeluaran terhadap kesejahteraan subjektif keluarga

\begin{tabular}{|c|c|c|c|}
\hline \multirow{2}{*}{ Model } & \multicolumn{2}{|c|}{ Koefisien B } & \multirow{2}{*}{ Sig. } \\
\hline & Tidak terstandarisasi & Terstandarisasi & \\
\hline \multicolumn{4}{|l|}{ Kesejahteraan subjektif istri } \\
\hline Konstanta & 50,649 & & 0,000 \\
\hline Usia istri (tahun) & 0,055 & 0,089 & 0,641 \\
\hline Lama pendidikan istri (tahun) & 0,099 & 0,042 & 0,802 \\
\hline Besar keluarga (orang) & $-1,139$ & $-0,291$ & 0,108 \\
\hline Jumlah Bagan (unit) & 2,112 & 0,336 & $0,086^{*}$ \\
\hline Pendapatan/kapita (Rp000/bulan) & $-4,713$ & $-0,120$ & 0,571 \\
\hline Pengeluaran untuk pangan pokok (persentase) & $-0,092$ & $-0,070$ & 0,708 \\
\hline Pengeluaran untuk jajanan (persentase) & 0,018 & 0,021 & 0,889 \\
\hline Pengeluaran untuk kesehatan (persentase) & $-0,528$ & $-0,130$ & 0,377 \\
\hline Pengeluaran untuk pendidikan (persentase) & 0,169 & 0,212 & 0,186 \\
\hline Pengeluaran untuk pakaian (persentase) & $-0,077$ & $-0,032$ & 0,849 \\
\hline Pengeluaran untuk komunikasi (persentase) & 0,874 & 0,395 & $0,015^{\star \star}$ \\
\hline Pengeluaran untuk kegiatan sosial (persentase) & 1,705 & 0,303 & $0,081^{*}$ \\
\hline $\mathrm{F}$ & & 1,712 & \\
\hline Sig & & 0,104 & \\
\hline Adjusted $R$ Square & & 0,148 & \\
\hline \multicolumn{4}{|l|}{ Kesejahteraan subjektif suami } \\
\hline Konstanta & 71,607 & & 0,000 \\
\hline Usia suami (tahun) & $-0,094$ & $-0,098$ & 0,619 \\
\hline Lama pendidikan suami (tahun) & 0,515 & 0,157 & 0,338 \\
\hline Besar keluarga (orang) & $-1,994$ & $-0,330$ & $0,058^{*}$ \\
\hline Jumlah Bagan (unit) & 1,452 & 0,149 & 0,432 \\
\hline Pendapatan/kapita (Rp000/bulan) & $-4,339$ & $-0,072$ & 0,714 \\
\hline Pengeluaran untuk pangan pokok (persentase) & 0,321 & 0,159 & 0,425 \\
\hline Pengeluaran untuk jajanan (persentase) & $-0,094$ & $-0,070$ & 0,650 \\
\hline Pengeluaran untuk kesehatan (persentase) & 0,030 & 0,030 & 0,864 \\
\hline Pengeluaran untuk pendidikan (persentase) & $-1,669$ & $-0,266$ & $0,087^{*}$ \\
\hline Pengeluaran untuk pakaian (persentase) & 0,089 & 0,072 & 0,646 \\
\hline Pengeluaran untuk komunikasi (persentase) & 1,520 & 0,444 & $0,006^{\star \star}$ \\
\hline Pengeluaran untuk kegiatan sosial (persentase) & 1,771 & 0,203 & 0,192 \\
\hline $\mathrm{F}$ & & 1,958 & \\
\hline Sig & & 0,058 & \\
\hline Adjusted $R$ Square & & 0,190 & \\
\hline
\end{tabular}

Keterangan: *signifikan pada $p<0,1 ;{ }^{* *}$ signifikan pada $p<0,05$

\section{PEMBAHASAN}

Penelitian ini bertujuan untuk menganalisis alokasi pengeluaran dan kesejahteraan keluarga nelayan bagan di Desa Sarang Tiung. Kondisi sosial ekonomi masyarakat wilayah pesisir umumnya sangat memprihatinkan yang ditandai dengan rendahnya tingkat pendidikan, produktivitas, dan pendapatan. Hampir setengah dari jumlah responden hanya menamatkan pendidikan hingga Sekolah Dasar (SD). Hasil ini sejalan dengan penelitian yang dilakukan oleh Muflikhati (2010) yang menyebutkan rata-rata tingkat pendidikan nelayan adalah tingkat pendidikan dasar. Tingkat pendidikan yang rendah akan berdampak pada pola fikir, wawasan, dan pola kehidupan (Muflikhati, 2010).
Meskipun pendapatan nelayan Desa Sarang Tiung berada di atas garis kemiskinan, akan tetapi kerentanan dalam hal ekonomi tetap saja ada, karena selama setahun, nelayan hanya dapat melaut secara produktif sekitar tujuh bulan. Bulan Agustus hingga Desember terjadi cuaca buruk (angin dan gelombang tinggi), sehingga aktivitas melaut dihentikan sementara. Nelayan bagan Desa Sarang Tiung menyebut musim tersebut dengan musim Tenggara. Nelayan Desa Gebang Kabupaten Cirebon menyebutnya dengan musim paila (paceklik) dan hal ini biasanya terjadi pada bulan Juli sampai dengan Desember atau pada saat musim penghujan (Muflikhati, 2010). Menurut Hamudy (2008) kemiskinan bukan hanya terkait pada masalah kekurangan materi untuk hidup layak secara 

sosial tetapi kemiskinan juga merupakan bentuk ketidakmampuan dalam mengakses fasilitas kesejahteraan sosial. Kemiskinan nelayan di Kabupaten Pamekasan disebabkan oleh faktor alam, budaya, dan struktur

Salah satu indikator kesejahteraan keluarga adalah dengan mengukur besarnya pengeluaran. Rata-rata pengeluaran keluarga nelayan bagan Desa Sarang Tiung adalah Rp5.123.910,00 per bulan. Proporsi terbesar pengeluaran keluarga masih untuk pengeluaran pangan yaitu 61,06 persen dan sisanya untuk pengeluaran nonpangan sebesar 38,94 persen. Teori Engel menyebutkan bahwa besarnya pengeluaran pangan daripada pengeluaran nonpangan menandakan keluarga tersebut belum sejahtera. Rokok merupakan pengeluaran pangan terbesar kedua setelah jajanan. Hasil penelitian sebelumnya juga menyatakan bahwa rokok menyumbang persentase yang besar untuk pengeluaran pangan keluarga (Muflikhati, 2010; Novita \& Mukhyar, 2011; Rambe, Hartoyo, \& Karsin, 2008). Terdapat 16,0 persen keluarga yang memiliki kondisi keuangan defisit. Hasil penelitian sebelumnya juga masih menemukan 40,4 persen keluarga dengan kondisi keuangan defisit, baik keluarga nelayan maupun bukan nelayan (Muflikhati, 2010). Kemiskinan masyarakat pesisir tidak hanya terbatas pada tingkat pendapatan yang rendah tetapi juga disebabkan oleh ketidakmampuan dalam mengelola pengeluaran rumah tangga.

Pengeluaran untuk kegiatan sosial relatif kecil, yaitu 1,89 persen dari total pengeluaran keluarga. Cahyono, Nugroho, dan Indrajaya (2007) menjelaskan kecilnya persentase pengeluaran kegiatan sosial meskipun dalam pengamatan di lapangan biaya kegiatan sosial cukup besar adalah karena: 1) bentuk sumbangan, iuran tersebut sebagian besar bukan berupa uang tetapi berupa natura dan tenaga, sehingga sumbangan dalam bentuk uang relatif kecil; 2) memberi bantuan dalam bentuk uang akan mengganggu keharmonisan hubungan masyarakat desa; 3) petani desa cenderung melupakan bantuan yang telah diberikan karena khawatir tidak ikhlas dalam memberi bantuan; 4) kerendahan hati dan tidak menonjolkan diri dalam sumbangan/membantu orang lebih dihargai.

Berdasarkan 14 kriteria rumah tangga miskin menurut BPS, sebagian besar $(76,0 \%)$ keluarga nelayan bagan termasuk dalam kategori tidak miskin. Hasil penelitian Lindawati dan Saptanto (2014) juga menyebutkan bahwa sebesar $(63,0 \%)$ keluarga pembudidaya ikan tergolong tidak miskin berdasarkan 14 kriteria rumah tangga miskin menurut BPS. Rendahnya persentase keluarga miskin berdasarkan 14 kriteria Badan Pusat Statistik (BPS) disebabkan terlalu rendahnya garis kemiskinan yang digunakan (Rambe, Hartoyo, \& Karsin, 2008).

Suami lebih sejahtera daripada istri baik pada dimensi fisik-ekonomi, sosial, maupun psikologis. Berdasarkan hasil uji beda terdapat perbedaan yang signifikan antara kesejahteraan subjektif suami dan kesejahteraan subjektif istri. Menurut (Wood, Rhodes, \& Whelan, 1989) bahwa perbedaan jenis kelamin berpengaruh terhadap kesejahteraan subjektif. Penelitian ini menunjukkan bahwa suami merasa lebih sejahtera daripada istri. Berbeda dengan penelitian sebelumnya yang menyatakan bahwa perempuan lebih melaporkan kebahagiaannya dan kepuasan hidupnya yang lebih besar daripada laki-laki, sehingga perempuan merasa lebih sejahtera (Wood, Rhodes, \& Whelan ,1989). Diduga suami lebih menghabiskan waktunya untuk mencari nafkah dan tidak terlalu memikirkan hal-hal yang tidak dimiliki, sehingga lebih fokus pada apa yang diperoleh saat ini dan cenderung mensyukuri keadaan. Syarief dan Hartoyo (1993) menyatakan bahwa keluarga dengan status miskin mungkin merasa lebih sejahtera karena lebih bersyukur, merasa cukup dan keinginan-nya sudah terpenuhi.

Jumlah bagan dan pengeluaran untuk kegiatan sosial merupakan variabel yang berpengaruh terhadap kesejahteraan subjektif istri. Besar keluarga dan pengeluaran untuk kesehatan berpengaruh negatif terhadap kesejahteraan subjektif suami. Sejalan dengan penelitian (Muflikhati et al., 2010; Hartoyo \& Aniri, 2010) menyebutkan bahwa pada umumnya besar keluarga merupakan faktor yang berpengaruh terhadap kesejahteraan keluarga. Diduga dengan bertambahnya pengeluaran untuk kesehatan akan menambah beban suami sebagai pencari nafkah dan akan menurunkan kesejahteraan subjektif suami. Keluarga yang memiliki besar keluarga kecil memiliki kesempatan yang lebih besar untuk sejahtera karena jumlah tanggungan keluarga lebih sedikit (Muflikhati et al., 2010). Pengeluaran untuk komunikasi merupakan faktor yang memengaruhi kesejahteraan subjektif suami dan istri. Diduga dengan meningkatnya komunikasi yang terjalin antara suami, istri, dan kerabat akan membuat keluarga semakin dekat dan dapat meningkatkan kesejahteraan keluarga. Penelitiaan sebelumnya menyebutkan bahwa faktor yang memengaruhi kesejahteraan subjektif istri 

adalah lama pendidikan istri, lama pendidikan suami, besar keluarga, usia istri (Johan, Muflikhati, \& Mukhti, 2013).

\section{SIMPULAN DAN SARAN}

Pengeluaran keluarga nelayan bagan sebagian besar masih digunakan untuk pengeluaran pangan. Sebagian besar nelayan bagan sudah termasuk dalam kategori sejahtera berdasarkan 14 kriteria rumah tangga miskin penerima BLT dan tidak ada yang memiliki pendapatan di bawah garis kemiskinan Kabupaten Kotabaru. Suami merasa lebih sejahtera daripada istri. Peningkatan dalam hal jumlah bagan, pengeluaran untuk komunikasi, dan pengeluaran untuk kegiatan sosial dapat meningkatkan kesejahteraan subjektif istri dari keluarga nelayan bagan. Kesejahteraan subjektif suami menurun dengan bertambahnya jumlah anggota keluarga dan bertambahnya pengeluaran keluarga untuk kesehatan. Akan tetapi, kesejahteraan subjektif suami meningkat dengan bertambahnya pengeluaran untuk komunikasi.

Berdasarkan hasil, penelitian ini menyarankan agar pemerintah melakukan penyuluhan terkait manajemen keuangan kepada keluarga (rumah tangga) nelayan agar dapat membuat skala prioritas dan dapat mengatur keuangan dengan baik. Dengan membuat skala prioritas diharapkan keluarga nelayan mampu mengelola pengeluarannya sesuai kebutuhan bukan keinginan.

\section{DAFTAR PUSTAKA}

[BPS] Badan Pusat Statistik. (2008). Berita resmi statistik: Perubahan jumlah penduduk miskin provinsi Jawa Barat. Jakarta.

Cahyono, S. A., Nugroho, N. P., \& Indrajaya, Y. (2007). Alokasi pengeluaran rumah tangga penyadap getah pinus di Desa Somagede, Kabupaten Kebumen, Jawa Tengah. Jurnal IImu Kehutanan, 1(1). Diambil dari: http://jurnal.ugm.ac.id/jikfkt/article/view/15 38. [Diunduh 21 Januari 2015].

Crona, B., Nystrom, M., Folke, C., \& Jiddadwi, N. (2010). Middlemen, a critical socialecological link in coastal communities of Kenya and Zanzibar. Marine Policy, 34, 761-771.

Elmanora, Muflikhati, I., \& Alfiasari. (2012). Kesejahteraan keluarga petani kayu manis. Jur. IIm. Kel \& Kons., 5(1), 58-66.
Firdaus, M., Apriliani, T., Wijaya, R. A. (2013). Pengeluaran rumah tangga nelayan dan kaitannya dengan kemiskinan: Kasus di Desa Ketapang Barat, Kabupaten Sampang, Jawa Timur. J Sosek Kp, 8(1).

Girsang, W. (2012). Analisis pendapatan rumah tangga dan kemiskinan di pedesaan Maluku (studi kasus di Desa Lohiatala Kabupaten Seram bagian Barat, Provinsi Maluku). Jurnal Agrinimal, 2(2), 44-54.

Hamudy, M. I. A. (2008). Pengentasan rakyat miskin dan pembangunan manusia di Jawa Barat (Tesis). Program Pasca Sarjana Universitas Padjadjaran, Bandung.

Hartoyo, \& Aniri N. B. (2010). Analisis tingkat kesejahteraan keluarga pembudidaya ikan dan nonpembudidaya ikan di Kabupaten Bogor. Jur. IIm. Kel \& Kons., 3(1), 64-73.

Iberahim. (2013). Upaya pemerintah Kabupaten Kotabaru dalam pengentasan kemiskin-an masyarakat nelayan di Kecamatan Pulau Laut Utara. Jurnal IImu Politik dan Pemerintahan Lokal, 2(2), 287-294.

Iskandar, A. (2007). Analisis praktlk manajemen sumber daya keluarga dan dampaknya terhadap kesejahteraan keluarga di Kabupaten dan Kota Bogor (Disertasi). Sekolah Pascasarjana, Institut Pertanian Bogor, Bogor.

Johan, I. R., Muflikhati, I., \& Mukhti, D. S. (2013). Gaya hidup, manajemen keuangan, strategi koping, dan kesejahteraan keluarga. Jur. IIm. Kel \& Kons., 6(1), 30-38.

[KKP] Kementerian Kelautan dan Perikanan. (2011). Kelautan dan perikanan dalam angka 2013. Diambil dari http:// statistik.kkp.go.id/index.php/arsip/file/37/kp da11_ok_r06_v02.pdf.

Lindawati. \& Saptanto, S. (2014). Analisis kemiskinan dan ketahanan pangan berdasarkan tingkat pengeluaran konsumsi pada rumah tangga pembudidaya ikan (studi kasus di Desa Sumur Gintung, Kabupaten Subang, Jawa Barat). J. Sosek $K P, 9(2)$.

Muflikhati, I. (2010). Analisis pengembangan model peningkatan kualitas sumber daya manusia dan kesejahteraan keluarga di wilayah pesisir Provinsi Jawa Barat (Disertasi). Sekolah Pascasarjana, Institut Pertanian Bogor, Bogor.

, Hartoyo, Sumarwan, U., Fahrudin, A., \& Puspitawati, H. (2010). Kondisi sosial ekonomi dan tingkat kesejahteraan 

keluarga: kasus di wilayah pesisir Jawa Barat. Jur. IIm. Kel \& Kons., 3(1), 1-10.

Novita, S., \& Mukhyar, F. (2011). Kajian: Pola pengeluaran pangan rumahtangga petani padi sawah di Kabupaten Banjar Kalimantan selatan. Jurnal Agribisnis Perdesaan, 1(4).

Primyastanto, M., Soemarno, Efani, A., \& Muhammad, S. (2012). Kajian ekonomi rumah tangga nelayan payang di Selat Madura Jawa Timur. Jurnal Perikanan dan IImu Kelautan, 15(2). Diambil dari http://wacana.ub.ac.id/index.php/wacana/a rticle/view/253. [Diunduh pada 26 Juni 2015].

Rachman, H. P. S., Purwantini, T. B., \& Marisa, Y. (2006). Prospek diversifikasi usaha rumah tangga dalam mendukung ketahanan pangan dan penanggulangan kemiskinan. Forum Penelitian Agroekonomi, 24(1).

Rambe, A., Hartoyo, \& Karsin, E. S. (2008). Analisis alokasi pengeluaran dan tingkat kesejahteraan keluarga (Studi di Kecamatan Medan Kota, Sumatera Utara). Jur. IIm. Kel. \& Kons, 1(1), 16-28.

Sunarti, E. (2001). Studi ketahanan keluarga dan ukurannya: Telaah kasus pengaruh- nya terhadap kualitas kehamilan (Disertasi). Institut Pertanian Bogor, Bogor.

Sunarti, E. (2006). Indikator keluarga sejahtera: Sejarah pengembangan, evaluasi, dan keberlanjutannya. Bogor, ID: IPB Press.

Praptiwi, R. N., \& Muflikhati, I. (2011). Kelentingan keluarga, dukungan sosial,dan kesejahteraan keluarga nelayan juragan dan buruh di daerah rawan bencana. Jur. IIm. Kel \& Kons., 4(1), 1-10. (2013). Ketahanan keluarga. Bogor, ID: IPB Press.

Syarief, H., \& Hartoyo. (1993). Beberapa aspek dalam kesejahteraan keluarga. Di dalam: Kusno, S. R., Martianto, D., Dwirianti, E. M., Pranadji, D. K., editor. Seminar Keluarga Menyongsong Abad 21 dan Peranannya dalam Pengembangan Sumberdaya Manusia Indonesia; 1993 September 21-22; Bogor, Indonesia. Bogor, ID: IPB Press. HIm-73-79.

Wood, W., Rhodes, N., \& Whelan, M. (1989). Sex differences in positive well-being: a consideration of emotional style and marital status. Journal of American Psycological Association, 106(2), 294-264. America, US: Texas A \& M University. 